\title{
Peculiarities of Labour Income Taxation in the Baltic States $^{1}$
}

\author{
Ilona Skačkauskienè
}

\begin{abstract}
A B S T R A C T
Objective: The main objective of the paper is to analyse the peculiarities of the taxation of labour income in the Baltic States (Lithuania, Latvia and Estonia).

Research Design \& Methods: The influence of the basic tax elements on the evaluation of the level of labour income taxation was investigated. The comparative and logical analysis of statistical data and literature was performed and synthesis methods were applied. During the research, Latvia and Estonia, the countries closely related to Lithuania, have been compared.
\end{abstract}

Findings: The labour income taxation (with personal income tax, social security and compulsory health insurance) in Lithuania is the lowest when compared with labour income taxation in Latvia and Estonia.

Implications \& Recommendations: The results of the research have shown that the comparison of the basic tax indicators, such as non-taxable minimum income and standard rates, only partially describe the national level of the labour income taxation. A more accurate description of the tax level could be provided only after applying ratios and evaluating such factors as tax base and tax exemptions.

Contribution \& Value Added: The paper delivers new empirical evidence on labour income taxation in different countries.

\begin{tabular}{ll}
\hline Article type: & research paper \\
Keywords: & labour income; taxation; contribution; tax; indicators \\
JEL codes: & $\mathrm{H} 24, \mathrm{H} 71$
\end{tabular}

Published by Centre for Strategic and International Entrepreneurship - Krakow, Poland

\section{Suggested citation:}

Skačkauskienè, I. (2013). Peculiarities of Labour Income Taxation in the Baltic States. Entrepreneurial Business and Economics Review, 1(4), 57-69.

\footnotetext{
1 The article is a revised version of a paper presented at the 2 nd International Scientific Conference "Contemporary Issues in Business, Management and Education 2013“, Vilnius, Lithuania, November 14-15, 2013.
} 


\section{INTRODUCTION}

Income taxation is one of the most complicated elements of the state tax policy - it is the goal of the state to ensure sufficient revenue into the state budget as well as create a favourable labour taxation environment (high tax on labour income stimulates migration of labour force and, when generous social policy comes along, it encourages living on benefits). The fact that this area has become especially sensitive can be proven by the recent changes in income taxation introduced in most countries during last years: gradual reform of personal income tax has been implemented in Denmark since 2009; France has increased the top income tax rate for high-income earners since 2013; in 2011 Hungary changed the progressive personal income tax rate into a $16 \%$ proportional rate; Latvia has been decreasing its personal income tax rate since 2011; since 2009, Poland has imposed two income tax rates (18 and 32\%) instead of the former 3 ones (19; 30 and 40\%); as of 2014 Lithuania will start increasing the non-taxable amount of income. During the last ten years fundamental changes took place in the Lithuanian tax system (in improving tax administration, legal framework and taxation mechanism). It should be noted that the improvement of labour income taxation is one of the priorities of the Government of the Republic of Lithuania (SRL, 2012). It is often stated, however, that very high taxes are withheld from labour income in Lithuania. The aim of the research is to reveal the actual level of the Lithuanian labour income taxation and to perform a comparative analysis of income taxation in the Baltic states (i.e. Latvia and Estonia). Comparative and logical analysis of statistical data and literature was performed and synthesis methods were applied in conducting this research.

The issue of taxes is widely researched both in professional and scientific literature and quite a lot of attention is paid to different taxation aspects. Taxation principles, functions of tax system, its conception were studied by Cheung (2001), Tušaitè (2003), Šinkūnienė (2005), Ivaškaitè-Tamošiūnè (2013), evaluation of its components was performed by Klun (2003), Lukyanenko (2003), Budrytė and Mačiulaitytè (2004), Lambert (2004), Medelienė (2005), Toder (2007), Mažeika (2008), Skačkauskienė (2011). The article does not aim to develop the measures to improve labour income taxation. On the contrary, it raises the question of practical assessment of labour income taxation - whether comparison of the core elements in labour income taxation allows an objective evaluation of the extent of income taxation in a country. Such a research, having made comparisons of the main tax components in the Baltic States, and having compared them to the relative indicators, would allow us to make conclusions about the validity of the evaluation.

\section{LITERATURE REVIEW}

\section{Concept of Labour Income}

In economics the income of a person during a certain period of time - is the amount of money that he or she could spend without decreasing the value of his or her capital (Black et al., 2013). These are earnings or income received that can be spent on consumption or savings. In order to get the income to satisfy their needs, people use 
such resources as personal skills and talents, as well as physical property and financial assets. These resources provide income that can be classified into four categories according to the source of income (Table 1).

Table 1. The main sources of personal income

\begin{tabular}{|c|c|c|}
\hline No. & Sources of Income & Essence \\
\hline 1. & Employment income & $\begin{array}{l}\text { Labour remuneration according to the level of qualification of the } \\
\text { employee, complexity of work, responsibilities, conditions, etc. }\end{array}$ \\
\hline 2. & $\begin{array}{l}\text { Self-employment } \\
\text { income }\end{array}$ & $\begin{array}{l}\text { Revenues derived from self-employment work in agriculture, } \\
\text { business, crafts, and free professional activities }\end{array}$ \\
\hline 3. & $\begin{array}{l}\text { Income from financial } \\
\text { assets }\end{array}$ & Interests, rental income, dividends \\
\hline 4. & $\begin{array}{l}\text { Income in the form of } \\
\text { social benefits }\end{array}$ & Pensions, allowances \\
\hline
\end{tabular}

Source: (Blažienè, 2002, p. 12).

The methodology of Statistics Lithuania (SLG, 2010) defines the combined household income as all the income of the household received from employment or selfemployment, property income or land rental, social benefits, regular cash transfers from other households, dividends and other income. It is obvious that, according to this methodology, an inhabitants' income is the sum of different kinds of income - salary, income from personal business, rent as well as transferrable state allowances (EC, 2013a). The Law on Personal Income Tax of the Republic of Lithuania (SRL, 2002) defines income as positive income, remuneration for the works or services performed, assets or funds sold or otherwise transferred or invested and any other benefit in cash and/or in kind. This legal definition corresponds to the forms of income 1-3 as specified in Table 1 above.

The labour income is also defined as a traditional way of earning money, i.e. selling man-hours for a certain fee (Ramsden, 2007). The Law on Personal Income Tax defines employment related income or corresponding income as follows: income received for the work performed under the contract of employment or corresponding contracts as well as income received by the owner of a sole proprietorship from a sole proprietorship, a general partner of a general partnership or a member of small partnership from a corresponding partnership. In this case work labour income is treated as remuneration for work performed - income that an employee receives for his or her work (see line 1 in Table 1). Usually, employment income is the main source of personal income. In 2012 in Lithuania, for example, remuneration for work accounted for about $70 \%$ of all personal income (SLG, 2013). It is also the main source of revenue of the state from direct taxes. In 2012, personal income tax revenue labour income accounted for $81.1 \%$ of all the revenues from this tax.

There are four types of taxes and contributions imposed on labour income in Lithuania: personal income tax, state social insurance, compulsory health insurance and guarantee fund contributions. These taxes and contributions are regulated by relevant legislation presented in chronological order in Table 2 below. 
Table 2. Legislation regulating income taxation in Lithuania

\begin{tabular}{|c|c|c|}
\hline Year & Legal Act & Short Content (main provisions) \\
\hline 1990 & $\begin{array}{l}\text { Provisional Law on Income Tax of } \\
\text { Natural Persons of the Republic of } \\
\text { Lithuania (Official Journal "Valstybès } \\
\text { žinios", 1990, No. 31-742) }\end{array}$ & $\begin{array}{l}\text { Tax payers - persons receiving income, the object - } \\
\text { income of natural persons. There were } 8 \text { different } \\
\text { rates set. A progressive rate was imposed on income } \\
\text { received from the second job. Invalid as of } 01-01-2003 \text {. }\end{array}$ \\
\hline 1991 & $\begin{array}{l}\text { Law on State Social Security of the } \\
\text { Republic of Lithuania (Official Journal } \\
\text { „Valstybès žinios“, 1991, No. 17-447) }\end{array}$ & $\begin{array}{l}\text { The law defines the types of insurance as well as the } \\
\text { categories of the insured persons; insurance } \\
\text { management system principles, structure, the rights of } \\
\text { the subjects, their duties and responsibilities. The } \\
\text { amendments of the law entered into force on 01-01- } \\
2005 \text {. }\end{array}$ \\
\hline 1996 & $\begin{array}{l}\text { Law on Health Insurance of the Republic } \\
\text { of Lithuania (Official Journal „Valstybès } \\
\text { žinios“, 1996, No. 55-128) }\end{array}$ & $\begin{array}{l}\text { Defines persons whose health insurance is compulsory, } \\
\text { the basics of drawing the budget and compensating } \\
\text { the expenses, institutions responsible for arranging the } \\
\text { insurance, the rights of the insurance subjects, their } \\
\text { duties and responsibilities. The amended law entered } \\
\text { into force on 01-01-2003. }\end{array}$ \\
\hline \multirow[t]{2}{*}{2000} & $\begin{array}{l}\text { Law on Social Insurance of Occupational } \\
\text { Accidents and Occupational Diseases of } \\
\text { the Republic of Lithuania (Official } \\
\text { Journal „Valstybès žinios“, 1999, No. } \\
\text { 110-3207) }\end{array}$ & $\begin{array}{l}\text { Persons are compulsorily insured by the employer who } \\
\text { pays social insurance contributions from the gross } \\
\text { earnings of the employee for the work performed, the } \\
\text { rates of the contributions depend on the level of the } \\
\text { risk of the company's economic activity. }\end{array}$ \\
\hline & $\begin{array}{l}\text { Law on Guarantee Fund (Official Journal } \\
\text { „Valstybės žinios“, 2000, No. 82-2478) }\end{array}$ & $\begin{array}{l}\text { The payers - legal persons, the rate }-0.2 \% \text { of the } \\
\text { gross earnings of the employees from which state } \\
\text { social insurance contributions are calculated. }\end{array}$ \\
\hline 2003 & $\begin{array}{l}\text { Law on Personal Income Tax of the } \\
\text { Republic of Lithuania (Official Journal } \\
\text { „Valstybès žinios“, 2002, No. 73-3085) }\end{array}$ & $\begin{array}{l}\text { Defined the order of taxation on personal income, its } \\
\text { principles, the rights and duties of the payers. The } \\
\text { object - personal income. The object of the tax differs } \\
\text { depending on the permanent and non-permanent } \\
\text { residence in Lithuania. Two rates were set - } 15 \% \text { and } \\
33 \% \text {. According to the payment order, the income is } \\
\text { divided into two categories - A and B. In } 2005 \text { when an } \\
\text { amended law came into force, the main tax rate was } \\
\text { reduced as follows: starting from the second half of } \\
2006 \text { - to } 27 \% \text {, starting from } 1 \text { January } 2008 \text { - down to } \\
24 \% \text {. The rate as of } 2009 \text { was } 15 \% \text {. }\end{array}$ \\
\hline 2009 & $\begin{array}{l}\text { Law on Replacing Clauses } 2,6,8,15,16 \text {, } \\
17,18,19 \text { and Supplementing the Health } \\
\text { Insurance Law of the Republic of } \\
\text { Lithuania (Official Journal "Valstybès } \\
\text { žinios", 2008, No. 149-6022) }\end{array}$ & $\begin{array}{l}\text { Contributions for compulsory health insurance were } \\
\text { separated from the personal income tax, the 3, } 6 \text { and } \\
9 \% \text { contributions rates were set; compulsory insurance } \\
\text { on health insurance was introduced. }\end{array}$ \\
\hline
\end{tabular}

Source: own elaboration based on the legal acts included in the table.

\section{MATERIAL AND METHODS}

\section{Personal Income Taxation}

In order to analyse labour income taxation in Lithuania and compare it to labour income taxation in Latvia and Estonia we should, first of all, discuss the instituted minimum monthly wage that ensures minimal income of working people. Lithuania, Latvia and Estonia have established a minimum monthly (hourly) wage that the employer has to pay to the employee regardless of his or her position.

During the analysed period the minimum monthly wage both in Latvia and Estonia differs from that instituted in Lithuania. According to Eurostat (EC, 2013b) data, Lithuania 
had the lowest minimum wage from 2009 to 2012 (on 1 August 2012 the minimum monthly wage in Lithuania was increased to 850 LTL but, nevertheless, it remained the lowest one in comparison with other Baltic states), and in 2013 the lowest minimum wage was in Latvia (Figure 1).

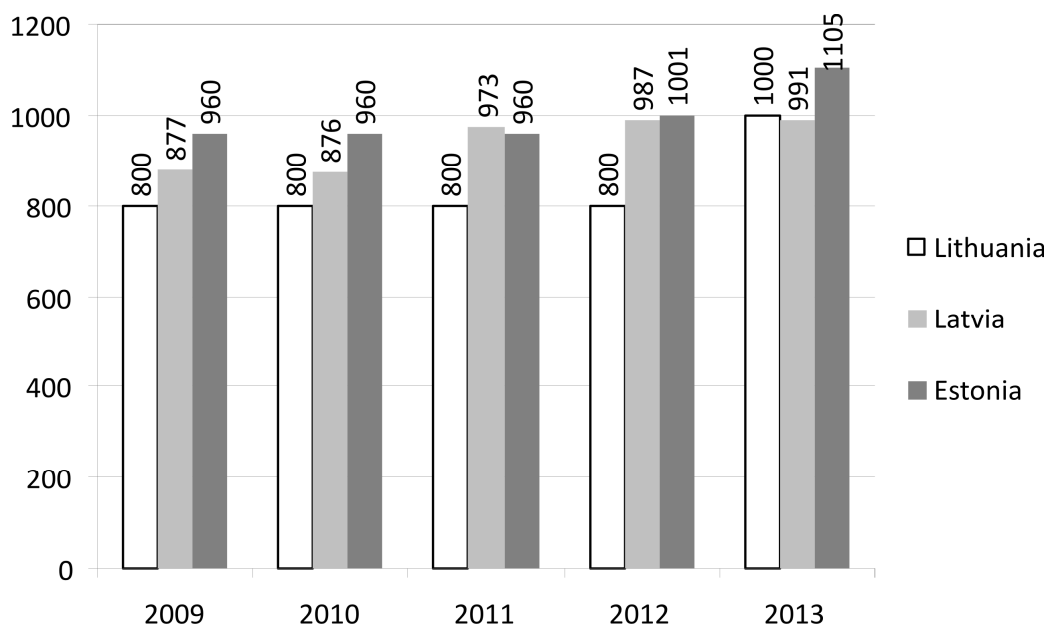

Figure 1. Dynamics of the minimum monthly wage in the Baltic States in years 2009-2013 (in LTL) Source: Eurostat (EC, 2013b).

The minimum monthly wage in Lithuania in 2013, as compared to 2009 , increased by $25 \%$, in Latvia $-13 \%$. The minimum remuneration in Estonia did not change over the period of 2009-2011 and in 2012 it increased by 41 LTL, in 2013 - by another 104 LTL and, if we compare the year 2009 and 2013, the minimum monthly wage here increased by $15 \%$. To sum up the issue of minimum wages in the three Baltic States, an observation can be made that the minimum monthly wages in Lithuania, Latvia and Estonia kept increasing. The minimum monthly wage in the period of 2009-2012 was the lowest in Lithuania whereas in 2013 it was the lowest in Latvia, which has been slightly overtaken by Lithuania ( $9 \mathrm{LTL})$.

Most countries, including the Baltic States, apply a non-taxable income amount on labour income. Table 3 presents the changes of the non-taxable income amount during the period of 2009-2013 (EC, 2013b). During the whole analysed period both in Lithuania and Estonia the main tax-exempt amount applied on personal income tax did not change. During the analysed period the tax-exempt amount applied on personal income in Lithuania reached $470 \mathrm{LTL}$, in Estonia - $27 \mathrm{LTL}$ (that is $5 \%$ ) more. As a matter of fact, starting from 2014 the established tax-exempt amount is going to be 570 LTL. Meanwhile, the tax-exempt amount on personal income in Latvia during the analysed period kept fluctuating and only in 2011 it settled and reached 222 LTL.

The biggest difference in the tax-exempt amount was in Estonia and Latvia in 2010 when the tax-exempt amount in Latvia was $148 \mathrm{LTL}$ whereas in Estonia it reached even 497 LTL, i.e. in Estonia the tax-exempt amount on the income of its inhabitants was more than 3 times bigger (if we compare Latvia and Lithuania, the difference is slightly smaller but also it exceeded 3 times). In 2013 the tax-exempt amount on personal income of the 
inhabitants of Lithuania is more than 2 times bigger than the one applied in Latvia and $5 \%$ smaller than in Estonia.

It is obvious that the highest non-taxable amount applied during the analysed period was in Estonia. Although the minimum wage in Latvia by the end of 2013 was $16 \%$ higher than in Lithuania, the non-taxable income amount was 2.5 times smaller. We may state a priori that, under such conditions, an employee in Latvia receiving a minimum monthly wage pays an income tax from a higher taxable income amount.

Table 3. Parameters related to personal income taxation in the Baltic States in years 2009-2013

\begin{tabular}{|c|c|c|c|c|c|c|}
\hline Indicator & Country & 2009 & 2010 & 2011 & 2012 & 2013 \\
\hline \multirow{3}{*}{$\begin{array}{l}\text { Tax-exempt } \\
\text { amount (in LTL) }\end{array}$} & Lithuania & 470 & 470 & 470 & 470 & 470 \\
\hline & Latvia & 173 & 148 & 222 & 222 & 222 \\
\hline & Estonia & 497 & 497 & 497 & 497 & 497 \\
\hline \multirow{3}{*}{$\begin{array}{l}\text { Standard rates } \\
\text { of personal } \\
\text { income tax }(\%)\end{array}$} & Lithuania & 15 & 15 & 15 & 15 & 15 \\
\hline & Latvia & 23 & 26 & 25 & 25 & 24 \\
\hline & Estonia & 21 & 21 & 21 & 21 & 21 \\
\hline
\end{tabular}

Source: own calculations based on data from the Statistics Lithuania (SLG, 2013) and Eurostat (EC, 2013b).

As mentioned above, an amount of non-taxable income is applied in taxation of labour income with personal income tax. The personal income tax is calculated according to the personal income tax rates set by every individual state.

The rate of personal income tax imposed in Lithuania and Estonia within the analysed period, i.e. from 2009 to 2013, did not change: during all the five years the personal income tax in Lithuania was 15\%, in Estonia - 21\% (Table 3). Meanwhile, the personal income tax rate in Latvia keeps slightly changing. The highest tax rate imposed in Latvia was in 2010. At that time it was 26\%. In 2011 it was reduced by 1 percent pointdown to $25 \%$ and in 2013 by one more percent point - down to $24 \%$. If we compare 2013 and the beginning of the analysed period (2009) the personal income rate in Latvia has increased by 1 percent point.

The personal income tax rate in Lithuania is the lowest among the Baltic States. During the analysed period the rate of this tax, if Lithuania and Estonia are to be compared, is smaller by 6 percent points. Therefore, if other conditions are excluded, we may state that taxation of personal income in Lithuania is lower than that of Estonia.

Comparison of the three Baltic States shows that the highest standard personal income tax rate is imposed on personal income in Latvia. Personal income tax rate in Latvia during 2011-2012 was 10 percent points higher than in Lithuania (in 2013 - 9 points higher). The biggest difference in rates between Latvia and Lithuania was in 2010 when personal income tax rate in Latvia was higher by 11 percent points.

To sum up the labour income taxation with a personal income tax, we can make an observation that even though the minimum monthly wage in Lithuania in 2009-2012 was the lowest one (on average by $21 \%$ as compared to Estonia and by $16 \%$ if compared to Latvia), the non-taxable income amount was on average 2.5 times bigger than in Latvia and only 5\% smaller than in Estonia. The imposed personal income tax rate in Lithuania during the analysed period was the lowest one as compared to other Baltic States - 40\% lower than in Estonia and on average 60\% lower than in Latvia. It can be assumed that the burden of taxable personal income in Lithuania is the lowest one: in 
2013 an employed person in Estonia that receives a minimum monthly wage pays 123.04 LTL in taxes, in Latvia - 184.56 LTL, and in Lithuania - only 85.5 LTL. The fact that the burden of personal income tax in Lithuania is the lowest one has also been confirmed by Eurostat data (EC, 2013c). For example, in 2011 the revenue from the personal income tax in Estonia was $5.3 \%$ of gross domestic product (GDP), in Latvia - 5.6\% of GDP and in Lithuania - only $3.5 \%$ of GDP (Eurostat methodology also includes other taxes directly related to income, such as church tax, etc.).

\section{Taxation of Labour Income with Contributions}

State social insurance and compulsory health insurance contributions are imposed on labour income in Lithuania. The total state social insurance contribution rate paid by the insurer and the insured (SSI) that is imposed on remuneration and other employment related income is $40 \%$. The insurer pays the main part - contributions of $31 \%$ and the insured pays contributions of $9 \%$ (Figure 2). An attention should be paid to the fact that this contribution rate also comprises the compulsory health insurance (CHI) contribution rate ( $3 \%$ paid by the employer and $6 \%$ paid by the employee). In order to clarify the structure of SSI contribution rate, it is necessary to discuss the changes implemented in 2006. Starting from 1 January 2006 the contribution rate for insurance against the accidents at work has been differentiated according to the insurers' risk and potential injury indicators in organisations. The social security contribution rate for accidents at work and occupational diseases that has to be paid by the insurer was set according to three affirmed groups of social security contribution rates: they are affirmed of annually through the law on confirming the budget indicators of the state social insurance fund. In 2012 group IV for social contributions on accidents at work and occupational diseases was added (this group is supposed to be the most risky, considering the level of hazardous works an enterprise), however, none of Lithuanian enterprises has been included into the list so far.

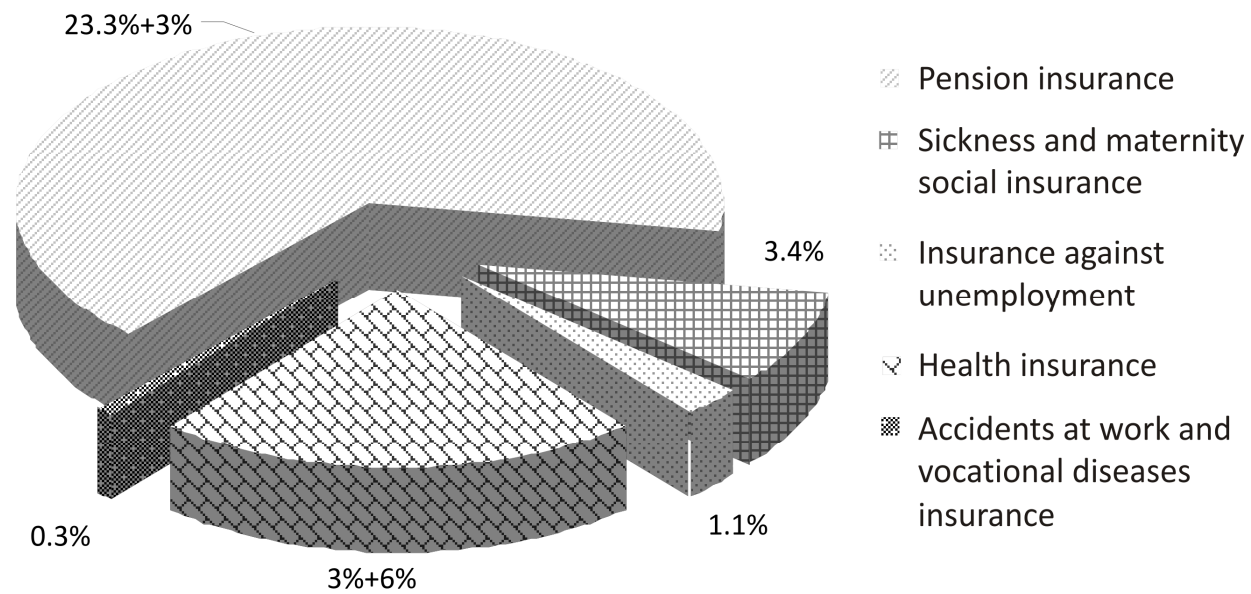

Figure 2. Distribution of the general rate of the state social insurance into different social insurance types in Lithuania in 2013 Source: The Seimas of the Republic of Lithuania (SRL, 2012). 
In 2008 the following general rates of state social insurance contributions were applied in Lithuania: $31 \%$ of the contribution (3\% of which was allocated to the compulsory health insurance) for the insurer, the insured had to pay $3 \%$ of the contributions. The biggest changes in state social insurance rates took place in 2009. First of all, the general SSI contribution rate significantly increased as a rate of $6 \%$ was affirmed of to be paid by the insured persons for the compulsory health insurance (earlier it was integrated into the income tax of natural persons and until 2009 the health insurance contributions had to be paid only by the insurers). Therefore, a new taxation rate scheme was introduced where the employer pays state social insurance contributions of $31 \%$ (with an integrated compulsory health insurance contribution rate of $3 \%$ ) and the employee pays a contribution of $9 \%$ (with an integrated compulsory health insurance contribution rate of $6 \%$ ). The pattern of paying sickness and maternity social insurance contributions has also changed. Since 2009 these contributions must be paid only by the insurers (i.e. the insured don't have to pay the $0.5 \%$ contributions on sickness and maternity social insurance). It should also be noted that since 2009 the insured has had to pay a 0.5 percent point higher rate of pension insurance contributions. But these changes have not had any significant influence on the total amount of contributions.

In 2013, as compared to 2012, the contribution rates on labour income did not change: the $31 \%$ rate paid by the insurer is allocated to different types of insurance - state social pension insurance, sickness and maternity social insurance, insurance against unemployment, accidents at work and occupational diseases insurance as well as health insurance. The $9 \%$ contribution rate paid by the insured is allocated to pension social insurance (3\%) as well as health insurance (6\%.). According to the Eurostat data (EC, 2013d), the social tax in Lithuania in 2012 is accounted for $11.3 \%$ of GDP and similarly in $2013-11.2 \%$ of GDP.

The amount of state social insurance contributions depends on the income amount received and declared by a person or the amount of the remuneration for work, however, persons with business licenses are an exception here. Attention must be paid to the fact that certain activities have a contribution base ceiling. It means that the income is exempt of taxes starting from the amount that exceeds the set insurable income amount. In the Resolution No. 5 of 9 January 2013 the Lithuanian government approved the taxable earnings amount of $1488 \mathrm{Lt}$. Such an amount, however, is not fixed for persons working and receiving income under employment agreements.

Similarly to Lithuania, in Latvia and Estonia labour income is taxed with state security and compulsory health insurance contributions. Compulsory social security contributions in Latvia are paid both by the employer and the employee. It should be noted that during the whole analyzed period 2009-2013 the contribution rate imposed on the employer in Latvia remained stable whereas the contribution rate levied on the employee kept changing. Starting from the beginning of the analyzed period until 2011 the contribution rate imposed on the employee reached 9\%, in 2011 the rate was increased by 2 percent point up to $11 \%$. Such a tendency has also remained in 2013 - the total contributions amount in 2013 is $35.09 \%, 24.09 \%$ of which is paid by the employer and $11 \%$ - by the employee. 
In Estonia the employer pays a social tax on the labour income of every employee before any other taxes. Revenues from this tax finances health and pension insurance. Differently from Lithuania and Latvia, the social tax is paid only by the employer (except the case when an employee participates in the second pillar funded pension scheme and transfers $2 \%$ from the remuneration before taxes to the personal pension account). During the whole analyzed period the social tax rate in Estonia remained unchanged $33 \%, 20 \%$ of which is allocated for pension insurance and $13 \%$ - health insurance contributions (besides, there is a maximum taxable base set -198720 LTL a year, above which contributions are not calculated). The employer and the employee are compulsorily insured against the unemployment, the contribution rate in 2012 was respectively 1.4 and $2.8 \%$ of the remuneration. According to the Eurostat data (EC, 2013d), the social tax in Estonia in 2012 is accounted for $11.6 \%$ of GDP.

Summarising, we may note that compulsory social insurance contributions must be paid in Latvia, a social tax which finances health and pension insurance is applied in Estonia, whereas in Lithuania people pay state social insurance as well as compulsory health insurance contributions. Each of the mentioned contributions differs not only in their names but also in contribution payers and contribution rates. Taxation of labour income with contributions as percentage of GDP is lowest in Latvia (EC, 2013d).

\section{RESULTS AND DISCUSSION}

The burdens of personal income taxation born by the inhabitants of Lithuania, Latvia and Estonia are different. In order to analyze the burden imposed on labour income, we compared the personal income tax, state social insurance and compulsory health insurance contribution rates and other related indexes of each country. Figure 3 shows personal labour income taxation in Lithuania, Latvia and Estonia in 2013.

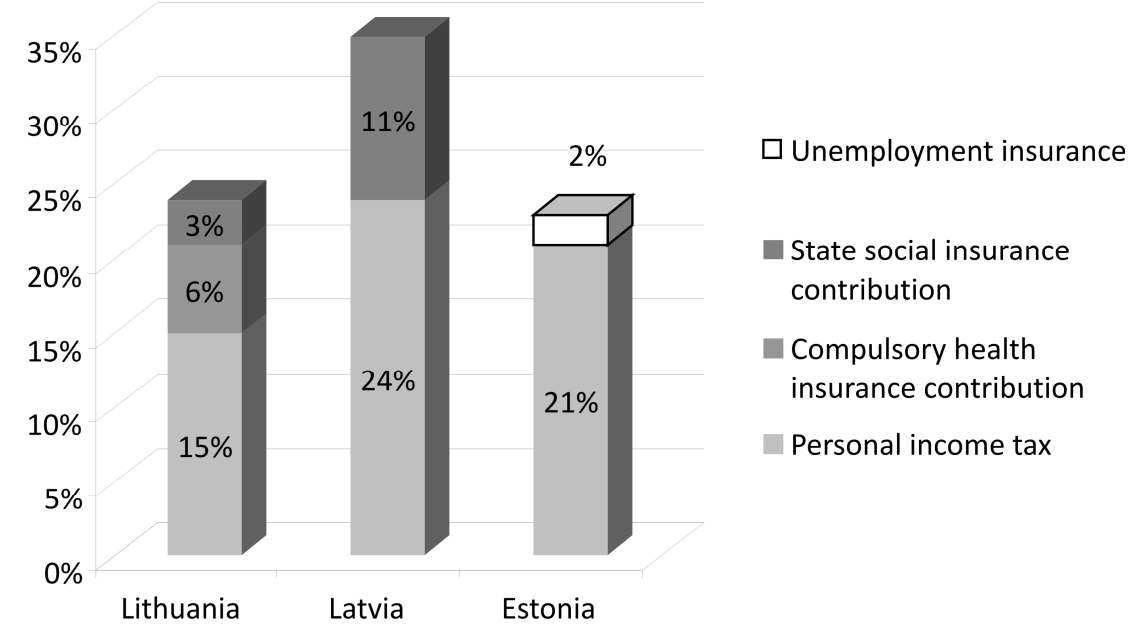

Figure 3. Standard rates of personal income taxes and contributions from the gross salary in the Baltic States in 2013

Source: Eurostat (EC, 2013d). 
We may tentatively note that in 2013 the highest rate of income taxation was specific to Latvia where personal income taxation rate was 35\%, $24 \%$ of which was personal income tax and $11 \%$ - compulsory social insurance contributions. Personal income in Lithuania is taxed at a rate of $24 \%$ (15\% of which are personal income tax, $3 \%$ state social insurance and $6 \%$ compulsory health insurance contributions), i.e. lower by 11 percent points than in Latvia. In Estonia the personal income is taxed at the rate of $23 \%$ (21\% of which constitute the personal income tax rate and $2 \%$ - insurance from unemployment) - which is lower than in Lithuania by 1 percent point and even 12 percent points lower than in Latvia. However, if we analyse the situation of the taxes paid by the employer from the earnings of a person, the situation is cardinally different: the highest burden is carried by Estonian employers - the taxes are higher than in Lithuania by 3 percent points and even by 9.91 percent points higher than those of the Latvian employers (Table 4).

Table 4. The main rates applied to employment earnings in the Baltic States in 2013 (in \%)

\begin{tabular}{|l|r|r|r|r|}
\hline \multicolumn{2}{|c|}{ Taxes and contributions } & \multicolumn{1}{c|}{ Lithuania } & \multicolumn{1}{c|}{ Latvia } & \multicolumn{1}{c|}{ Estonia } \\
\hline \multirow{2}{*}{ SSI and CHI } & Employer & 31 & 24.09 & 34 \\
\cline { 2 - 5 } & Employee & 9 & 11 & 2 \\
\hline Personal income tax & 15 & 24 & 21 \\
\hline Labour income taxation, \% of GDP (in 2011) & 12.7 & 13.8 & 16.8 \\
\hline
\end{tabular}

Source: own elaboration based on data from the Statistics Lithuania (SLG, 2013) and Eurostat (EC, 2013c).

It can be stated that labour income taxation in Lithuania, combined with personal income tax, social security and compulsory health insurance is the lowest one as compared with labour income taxation in Latvia and Estonia. If we analyze the taxation range (base - minimum monthly wage), i. e. how big is the gross salary of an employee, what income is at his or her disposal after taxes, as well as how much the employer has to pay in taxes from the gross salary of the employee, it can be stated that the smallest taxation range is in Lithuania, the highest in Latvia, and Estonia occupies the intermediate position. However, according to the data provided by the Eurostat database (EC, 2013b) on income taxation (as the percentage of GDP), the highest taxation burden is born by the Estonians and the smallest - by the Lithuanians. Another informative indicator provided by the Eurostat database is the implicit labour income tax rate - in 2011 it was the same in Latvia and Lithuania - 32.0\% and the highest in Estonia $(36.2 \%$.). This can be explained by the fact that there are lots of exceptions and exemptions in the Latvian (and Lithuanian) taxation system of labour income.

\section{CONCLUSIONS}

Labour income received by employed people for their work is the main source of personal income. Personal income tax and social security as well as health insurance taxes are imposed on labour remuneration. The main and the highest tax paid by employees on remuneration is personal income tax. Proportional tax rates are applied for calculating this tax in the Baltic states. There is a fixed non-taxable income size, the application of which adds features of progressiveness to the applicable taxation model. 
During the analyzed period the highest personal income tax rate as well as the lowest non-taxable amount was applied in Latvia. The lowest personal income tax burden was born by Lithuania.

Social security and health insurance contributions are imposed on labour income. Payment of these contributions, according to the proportion established by the state, is shared between the employer and the employee. In Lithuania (and Latvia also) it is the employer that pays the larger share of the taxes (respectively 31 and $24.09 \%$ ), the other smaller amount of contributions - respectively 9 and $11 \%$ - is deducted from the remuneration of the employee and other employment related income. Social tax in Estonia is paid only by the employer; however, the tax on unemployment social security is shared by the employer and the employee at the ratio of 1:2.

Although the performed research revealed that the highest rate of labour income taxation is applied in Latvia, the implicit tax rate shows that the average effective tax burden on the labour income is highest in Estonia. Comparison of the main taxation rates (non-taxable minimum, standard rates) only partially reveals the national level of the labour income taxation. A more accurate description of the taxation level can be provided only by having evaluated the taxation base of taxes and contributions, tax exemptions and having evaluated such factors as the implicit tax rate or taxation of labour income as the percentage of GDP.

\section{REFERENCES}

Black, J., Hashimzade, N., \& Myles, G. (2013). Dictionary of economics. Great Britain: Oxford University Press.

Blažienè, I. (2002). Population income and their normalization in Lithuania. Doctoral dissertation, Vilnius: Vilnius Gediminas Technical University.

Budrytė, A., \& Mačiulaitytė, E. (2004). Statutory and effective profit taxation in Lithuania. Pinigu studijos, 2, 54-78.

Butkevičius, A., \& Bivainis, J. (2009). Planning of National Budget Expenditure. Vilnius: Technika.

Cheung, D. (2001). Debate on the Hong Kong tax base - its criteria, principles, and problems. International Tax Journal, 2, 57-83.

European Commission (EC). (2013a). European household income by groups of households. Luxembourg: Publications Office of the European Union.

European Commission (EC). (2013b). Eurostat: Your key to European statistics. Retrieved on December 14, 2013, from http://epp.eurostat.ec.europa.eu/portal/page/portal/ eurostat/home

European Commission (EC). (2013c). Eurostat: Taxation trends in the European Union. Luxembourg: Publications Office of the European Union.

European Commission (EC). (2013d). Eurostat: Government finance statistics. Retrieved on November 19, 2013, from http://epp.eurostat.ec.europa.eu/tgm/table.do?tab=table\&init=1\&language=en\&pcode=tec0 0019\&plugin $=1$

Ivaškaitė-Tamošiūnè, V. (2013). Income redistribution in emerging welfare capitalism in Lithuania. Doctoral dissertation, Vilnius: Vilnius University. 
Klun, M. (2003). Administrative costs of taxation in a transition country: the case of Slovenia. Czech Journal of Economics and Finance, 53(1-2), 75-84.

Lambert, P. J. (2004). Income taxation and equity. Baltic Journal of Economics, 4(2), 39-54.

Lukyanenko, I. (2003). The concept of tax elasticity as a measure of tax system efficiency in Ukraine. Problems and Perspectives of Management, 1, 16-24.

Mažeika, A. (2008). The influence of the taxation system on small and medium-sized businesses. Doctoral dissertation. Vilnius: Vilnius University.

Medelienè, A. (2005). Theoretical and practical problems of tax dispute resolution. Doctoral dissertation. Vilnius: Vilnius University.

Ramsden, Ph. (2007). Finance for - non financial managers. London: Hodder Education, a division of Hodder Headline.

Skačkauskienė, I. (2013). Research on the dynamics of Lithuanian state revenue and preferences for expenditure allocation. Journal of Business Economics and Management, 14(4), 1-12.

Skačkauskienè, I. (2011). The change of the Lithuanian tax system: problems and actualities. Public Administration, 3(31), 16-29.

SRL (2012). The Resolution No XII-51of of 13 December 2012 of the Seimas of the Republic of Lithuania on The Government Program of the Republic of Lithuania. Official Gazette. 201212-20, No 149-7630.

Statistics Lithuania at the Government of the Republic of Lithuania (SLG). (2013) Official Statistics Portal. Retrieved on December 21, 2013, from http://osp.stat.gov.It/statistiniu-rodikliuanalize $? \mathrm{id}=2156 \&$ status $=\mathrm{A}$

Statistics Lithuania at the Government of the Republic of Lithuania (SLG). (2010) 'Order of the general director of Statistics Lithuania No. Dl-184', Methodology of a statistical research of income and living conditions. Retrieved on December 11, 2013, from http://osp.stat.gov.lt/documents/10180/559099/ES_PGS_

tyrimo_metodika20100929.pdf/a054b6cd-5279-418c-9f5b-b9482e9c466b

Šinkūnienè, K. (2005). Taxation principles in tax culture: theoretical and practical aspects. Organizacijy Vadyba: Sisteminiai Tyrimai, 35, 177-192.

The Seimas of the Republic of Lithuania (SRL). (2002). Law on Personal Income Tax of the Republic of Lithuania. Official Journal: Valstybès žinios, 73-3085.

The Seimas of the Republic of Lithuania (SRL). (2012). Law on Confirming the Indices of the Budget of the State Social insurance Fund for 2013 of the Republic of Lithuania. Official Journal: Valstybès žinios, No. 154-7919.

Toder, E. (2007). What is the tax gap?. Tax Notes, October, 1-12.

Tušaitè, J. (2003). Features of the new tax system. Jurisprudencija, 48(40), 107-121. 


\section{Author}

\section{Ilona Skačkauskienè}

Doctor of Social Sciences, Associate Professor, Head of the Department of Social Economics and Management, Vilnius Gediminas Technical University (Lithuania). Her research interests include: taxation, tax modelling and evaluating, tax system evaluation, budget revenue formation, social security, social and economic development. She has published over 30 publications and presented many papers at Lithuanian and international conferences.

\section{Correspondence to:}

Assoc. Prof. Ilona Skačkauskienè, PhD

Vilnius Gediminas Technical University

Faculty of Business Management

Saulètekio al. 11, LT-10223 Vilnius, Lithuania

ilona.skackauskiene@vgtu.lt 
